University of Michigan Law School

University of Michigan Law School Scholarship Repository

\title{
Dividend Policy Inside the Multinational Firm
}

\author{
Mihir A. Desai \\ Harvard University \\ C. Fritz Foley \\ Harvard University \\ James R. Hines Jr. \\ University of Michigan Law School, jrhines@umich.edu
}

Available at: https://repository.law.umich.edu/articles/1420

Follow this and additional works at: https://repository.law.umich.edu/articles

Part of the Business Organizations Law Commons, Taxation-Federal Commons, and the Taxation-

Transnational Commons

\section{Recommended Citation}

Hines, James R., Jr. "Dividend Policy Inside the Multinational Firm." M. A. Desai and C. F. Foley, co-authors. Fin. Mgmt. 36, no. 1 (2007): 5-26.

This Article is brought to you for free and open access by the Faculty Scholarship at University of Michigan Law School Scholarship Repository. It has been accepted for inclusion in Articles by an authorized administrator of University of Michigan Law School Scholarship Repository. For more information, please contact mlaw.repository@umich.edu. 


\title{
Dividend Policy Inside the Multinational Firm
}

\author{
Mihir A. Desai, C. Fritz Foley, and James R. Hines Jr.*
}

\begin{abstract}
This paper examines the determinants of profit repatriation policies for US multinational firms. Dividend repatriations are surprisingly persistent and resemble dividend payments to external shareholders. Tax considerations influence dividend repatriations, but not decisively, as differentiallytaxed entities feature similar policies and some firms incur avoidable tax penalties. Parent companies requiring cash to fund domestic investments, or to pay dividends to common shareholders, draw on the resources of their foreign affiliates through repatriations. Incompletely controlled affiliates are more likely than others to make regular dividend payments and to trigger avoidable tax costs through repatriations. The results indicate that traditional corporate finance concerns - taxation, costly external finance, and agency problems - are also critical to the internal capital markets of multinational firms.
\end{abstract}

The choice of whether to repatriate earnings from a foreign subsidiary is one of the most important decisions in multinational financial management. This paper identifies the factors that shape repatriation policy, thereby illuminating the functioning of the internal capital markets of multinational firms.

Dividend repatriations represent sizable financial flows. In 1999, a year in which US corporations listed in Compustat had after-tax earnings of $\$ 516$ billion and paid $\$ 198$ billion in dividends to common shareholders (Grullon and Michaely, 2002), the foreign affiliates of US multinational firms had after-tax earnings of $\$ 182$ billion and repatriated $\$ 97$ billion to the United States as dividends. Dividend repatriations are so large that part of the motivation for the partial repatriation tax holiday in 2005 was that the resulting inflow of funds from abroad might be large enough to have positive macroeconomic consequences for the US economy.

Surprisingly, relatively little is understood about the characteristics and determinants of the policies governing these payments. This paper analyzes the repatriation behavior of virtually all US multinational parent firms and their subsidiaries from 1982 to 2002. The paper identifies three factors that shape dividend policy within the multinational firm: 1) the taxation of dividend income, 2) domestic financing and investment needs, and 3) agency problems inside firms.

The statistical analysis of firm-level data on US multinational companies was conducted at the International Investment Division, Bureau of Economic Analysis, US Department of Commerce under arrangements that maintain legal confidentiality requirements. The views expressed are those of the authors and do not reflect official positions of the US Department of Commerce. The authors thank various seminar participants, two anonymous referees and Bill Christie (the editor) for helpful comments on an earlier draft and the Division of Research at Harvard Business School for financial support.

\footnotetext{
* Mihir A. Desai is the Rock Center Associate Professor at the Harvard Business School and Faculty Research Fellow at the National Bureau of Economic Research. C. Fritz Foley is an Assistant Professor of Finance at the Harvard Business School and Faculty Research Fellow at the National Bureau of Economic Research. James R. Hines Jr. is Richard A. Musgrave Collegiate Professor of Economics at the University of Michigan and Research Associate at the National Bureau of Economic Research.
} 
The flows of capital analyzed in this paper consist of payments to multinational parent firms declared out of the income of foreign subsidiaries. These flows do not include the repatriation of invested equity. As described below, tax considerations alone would suggest that dividend policies inside the firm would be irregular and lumpy. But in contrast to these predictions, dividend repatriations are quite regular and can be characterized by a process of partial adjustment that was first described by Lintner (1956). Multinational firms behave as though they select target payouts for their foreign affiliates, gradually adjusting payouts over time in response to changes in earnings. Current dividends by affiliates rise by roughly $\$ 0.40$ with every additional dollar of their after-tax profits. This pattern of persistent payouts does not appear to be an artifact of other regular investment or financing decisions at the affiliate level.

Comparing the behavior of foreign affiliates whose dividend repatriations are subject to high rates of tax with the behavior of affiliates whose dividends are not subject to tax illuminates the relevance of tax factors. Desai, Foley, and Hines (2001) show that firms pursue dividend payout policies designed in part to reduce tax obligations. However, further analysis shows that tax minimization cannot explain a significant portion of the dividend policies observed inside firms. Sharply distinctive tax treatments across organizational forms are associated with only modest differences in dividend policies. Some firms even appear to engage in a variety of tax-penalized behavior that involves the simultaneous repatriation of a dividend and investment of new equity in the same subsidiary.

Costly external finance may lead parent companies to seek cash dividends from their foreign affiliates to satisfy domestic financing and investment needs. For example, corporations that pay dividends to common shareholders could fund these payments by triggering repatriations. Comparing the dividend behavior of affiliates of publicly and privately held parent firms and introducing controls for parental dividend payouts indicates that a portion of external dividend payments are funded with repatriations from foreign affiliates. Surprisingly, only a small difference exists between the dividend repatriation policies of firms facing public capital market pressures to pay dividends to common shareholders and those that do not face such pressures.

Financially constrained parents with profitable domestic investment opportunities might finance capital expenditures by drawing on the accumulated earnings of foreign affiliates. This possibility is tested by measuring the extent to which the dividend policies of heavily leveraged firms in industries with high values of Tobin's $q$ differ from the dividend policies of other firms. The evidence indicates that firms with significant domestic cash needs arising from a combination of attractive domestic investment opportunities and high degrees of leverage repatriate cash from foreign affiliates to meet these needs.

Internal agency problems, or the inability to fully monitor foreign managers, can also bring about distinctive repatriation policies. Regular dividend payments restrict the financial discretion of foreign managers, thereby reducing associated agency problems. Conflicts of interest can arise when ownership is divided, since local owners may influence managers to undertake transactions at other than market prices. The empirical results discussed in this paper indicate that explicitly tax-penalized behavior is most common when affiliates are partially owned. This finding suggests that at least some of the regularity in dividend repatriations may be driven by control considerations inside the firm.

Taken as a whole, the results demonstrate that traditional corporate finance concerns - taxation, costly external finance, and agency problems - which are typically emphasized with respect to arms-length financing decisions, also influence the internal capital markets of multinational firms.

The paper is organized as follows. Section I of the paper summarizes tax and non-tax motivations for repatriation policies. Section II describes the data and provides some descriptive statistics. 
Section III presents analysis of the repatriation policies of foreign affiliates of American firms, and Section IV concludes.

\section{Motivations for Repatriation Policies}

Many previous studies of dividend repatriations analyze the effects of taxes. Dividend repatriations from foreign affiliates to American parent companies are voluntary distributions with tax consequences that are functions of their magnitude and timing. American corporations owe taxes to the United States on their foreign incomes but are entitled to defer US tax liabilities on the unrepatriated portions of the profits of incorporated foreign affiliates. The United States also permits firms to claim credits against US taxes for any foreign income taxes paid on income remitted as dividends. Dividend repatriations from foreign subsidiaries to their American parents thus generate US tax liabilities that are functions of differences between foreign tax rates and the US corporate tax rate.

Generally speaking, firms owe US taxes based on the difference between the applicable foreign tax rate and the US rate. If the US tax rate exceeds the foreign tax rate, then the effective repatriation tax equals the difference between the two. But if the foreign tax rate exceeds the US tax rate, then dividends do not trigger additional US tax liability and taxpayers can apply any difference against US tax liabilities on other foreign income. A notable exception to this treatment is that the dividend flows from unincorporated foreign branch affiliates and incorporated foreign affiliates that are indirectly owned through certain other countries do not have US tax consequences.

US taxes are due on foreign branch income as earned, regardless of whether the branch remits dividends to the parent company. If an affiliate is indirectly owned by a parent that uses a holding company located in a country that does not tax dividend repatriations, then the firm can generally relocate affiliate profits without incurring US tax costs. This distinction is important to the analysis of taxation and repatriation policies because it is possible to isolate the relative importance of tax factors by comparing the policies of incorporated and unincorporated foreign subsidiaries.

The desire to avoid US tax liabilities is likely to influence dividend repatriations in relatively straightforward ways. Given that US tax liabilities are triggered by repatriation, these tax liabilities can be deferred by reinvesting earnings abroad rather than remitting dividends to parent companies. The incentive to defer repatriation is much stronger for affiliates in low-tax countries whose dividends trigger significant US tax obligations than they are for affiliates in high-tax countries, particularly since taxpayers receive net credits for repatriations from affiliates in countries with tax rates that exceed the US rate. ${ }^{\prime}$ As a consequence of these incentives, dividend

\footnotetext{
'Hartman (1985) applies the "tax capitalization" or "new view" logic to the multinational firm to suggest that repatriation taxes need not affect multinational dividend policy if current repatriation tax conditions are not expected to change. In practice, there is ample evidence (see Altshuler, Newlon and Randolph (1995)) that conditions do change over time, thereby making it attractive to repatriate dividends opportunistically. Since excess foreign tax credits cannot be carried forward and back in time without loss of present value, even firms in unchanging tax situations face incentives to combine dividend repatriations from affiliates in high-tax and low-tax locations. Such strategies are costly and not always available, as a result of which repatriation taxes discourage dividend repatriations from affiliates, particularly those in low-tax countries. Desai and Hines (2004) find that US firms incurred \$20 billion of direct US tax liabilities on their foreign incomes in 1999, a figure that rises considerably when taking indirect costs into account, suggesting that taxpayers are unable to find cost-effective methods of avoiding all of their US tax liabilities on foreign income.
} 
policies that maximize value are thought to be irregular and lumpy to facilitate the averaging of credits across countries with different tax rates. ${ }^{2}$

Previous studies of dividend repatriations emphasize these tax factors. For example, Hines and Hubbard (1990) analyze a cross-section of US multinationals using IRS data from 1984, finding that tax considerations affect the timing of dividend repatriations. Other tax-focused studies of dividend policy inside the firm, such as Altshuler, Newlon, and Randolph (1995), use repeated cross-sections to distinguish effects associated with transitory and permanent changes in tax costs. Altshuler and Grubert (2003) and Desai, Foley and Hines (2003) note that firms can defer repatriation tax liabilities by investing foreign profits in other foreign affiliates rather than repatriating profits to domestic parent companies and provide evidence of the proliferation of organizational forms that facilitate such deferral. Finally, Desai, Foley and Hines (2001) calculate the efficiency costs of repatriation taxes using estimates of the responsiveness of repatriations to taxes in a panel setting.

There are strong reasons to expect dividend repatriation policies to reflect considerations other than tax factors. Since dividend repatriations represent significant financial flows, repatriation policies may reflect the financing concerns of parent firms that draw on subsidiary cash flows to finance domestic expenses. Two examples of such domestic expenses are dividend payments to external shareholders and capital expenditures in home countries. Since external finance can be quite costly, particularly for firms that are already maintaining large amounts of external debt, dividend repatriations from foreign affiliates may offer an attractive source of finance for paying dividends to common shareholders and domestic investment expenditures, despite possible associated tax costs.

The desire to control corporate managers around the world carries implications for dividend policies. A multinational firm's central management can use financial flows within the firm to evaluate the financial prospects and needs of far-flung foreign affiliates and to limit the discretion of foreign managers. In a 1998 speech to country managers, the CFO of Wyeth Pharmaceuticals identified several mechanisms of diversion by country managers, including using vendors to misappropriate corporate funds, employing unauthorized sales programs and trade promotions for personal benefit, and transacting with family-owned firms at the expense of the multinational firm. ${ }^{3}$ As this observation suggests, multinationals may find it sensible to mandate dividend payments to police and monitor foreign managers, limit their ability to misallocate funds, and to extract returns on investments, in much the same way as public shareholders use dividends to monitor and control their firms.

\section{Data and Descriptive Statistics}

The Bureau of Economic Analysis (BEA) Annual Survey of US Direct Investment Abroad from 1982 through 2002 provides a panel of data on the financial and operating characteristics of

\footnotetext{
${ }^{2}$ Some host countries, particularly some low-income countries in the earlier years of the sample, limit dividend repatriations through the use of capital controls. Desai, Foley and Hines (2006) find that dividend repatriations are responsive to tax incentives controlling for such policies.

${ }^{3}$ The speech by the Wyeth CFO was made public as part of a lawsuit brought by the general manager of the firm's Swedish subsidiary, who alleged that he was demoted for revealing alleged improprieties related to the tax treatment of compensation of foreign managers.
} 
the foreign and domestic activities of US multinational firms. ${ }^{4}$ The International Investment and Trade in Services Survey Act requires that all firms owning foreign affiliates with sales, assets, or net income greater than $\$ 7$ million in 1999 file detailed financial and operating items for each affiliate and information on the value of transactions between US parents and their foreign affiliates. The availability of this information makes the BEA survey sample uniquely comprehensive.

In the BEA survey, data on dividend payments made by affiliates reflect only those payments to stockholders declared out of current and prior period net income. Thus the data exclude other types of capital movement, such as the repatriation of funds associated with the sale of equity. Dividend payments from affiliates to their parent firms appear to be common, large, and persistent.

Figure 1 plots the percentage of affiliates that report positive dividends and the median payout ratio among payers for two types of affiliates-majority owned incorporated affiliates and branches-over the entire sample period. Averaging across the annual rates indicates that $31 \%$ of majority-owned incorporated affiliates and $27 \%$ of branches pay dividends. The median ratio of dividends to net income for payers (again averaging annual ratios across years) is $71 \%$ for majority-owned incorporated affiliates and $88 \%$ for branches. Foreign subsidiaries and foreign branches are somewhat equally likely to remit dividends, and do so with similar payout ratios.

Dividend payments exhibit strong intertemporal persistence. Averaging across years, $69 \%$ of affiliates that paid dividends in one year paid dividends again the following year. Figure 2 displays this rate for each year over the 1983-2002 period. This figure indicates that the rate of persistence remains high over the sample period.

\section{Empirical Design and Results}

The regression analysis detailed in this section exploits the panel nature of the data. Table I provides information on the means, medians, and standard deviations of variables used in the empirical work. ${ }^{5}$

The Lintner dividend model, first developed to analyze dividend payments from corporations to various common shareholders, provides an analytic framework with which to identify the nature of repatriation policies. Benartzi, Michaely, and Thaler (1997), among others, conclude that "Lintner's model of dividends remains the best description of the dividend setting process available." Accordingly, this paper considers the extent to which the Lintner model characterizes the repatriation policies of multinational affiliates, paying particular attention to how foreign earnings translate into dividends.

\footnotetext{
${ }^{4}$ Detailed information on the data collected in this survey appears in Appendix II of Desai, Foley and Hines (2002) and in Mataloni (1995). US direct investment abroad is defined as the direct or indirect ownership or control by a single US legal entity of at least $10 \%$ of the voting securities of an incorporated foreign business enterprise or the equivalent interest in an unincorporated foreign business enterprise. A US multinational entity is the combination of a single US legal entity that has made the direct investment, called the US parent, and at least one foreign business enterprise, called the foreign affiliate. The term affiliate refers to both subsidiaries, those affiliates incorporated abroad, and unincorporated branch affiliates.

${ }^{5}$ Minority-owned foreign affiliates are not part of the panel, as dividend payments are not recorded for these affiliates. The sample is selected to omit affiliates with the highest $1 \%$ of net income and lowest $1 \%$ of net income each year in order to enhance the robustness of the results. Also, calculated country tax rates are constrained to lie between $0 \%$ and $100 \%$, which entails adjustments to 226 affiliate-year observations.
} 
Figure 1. Propensity to Pay Dividends for Majority-Owned Incorporated Affiliates (MOIAs) and Branches, 1982-2002

Diamonds and squares indicate fractions of entities that remit dividends for majority owned incorporated affiliates and branches, respectively. Triangles and X's depict the median ratios of dividends to net income for majority owned incorporated affiliates and branches, respectively.

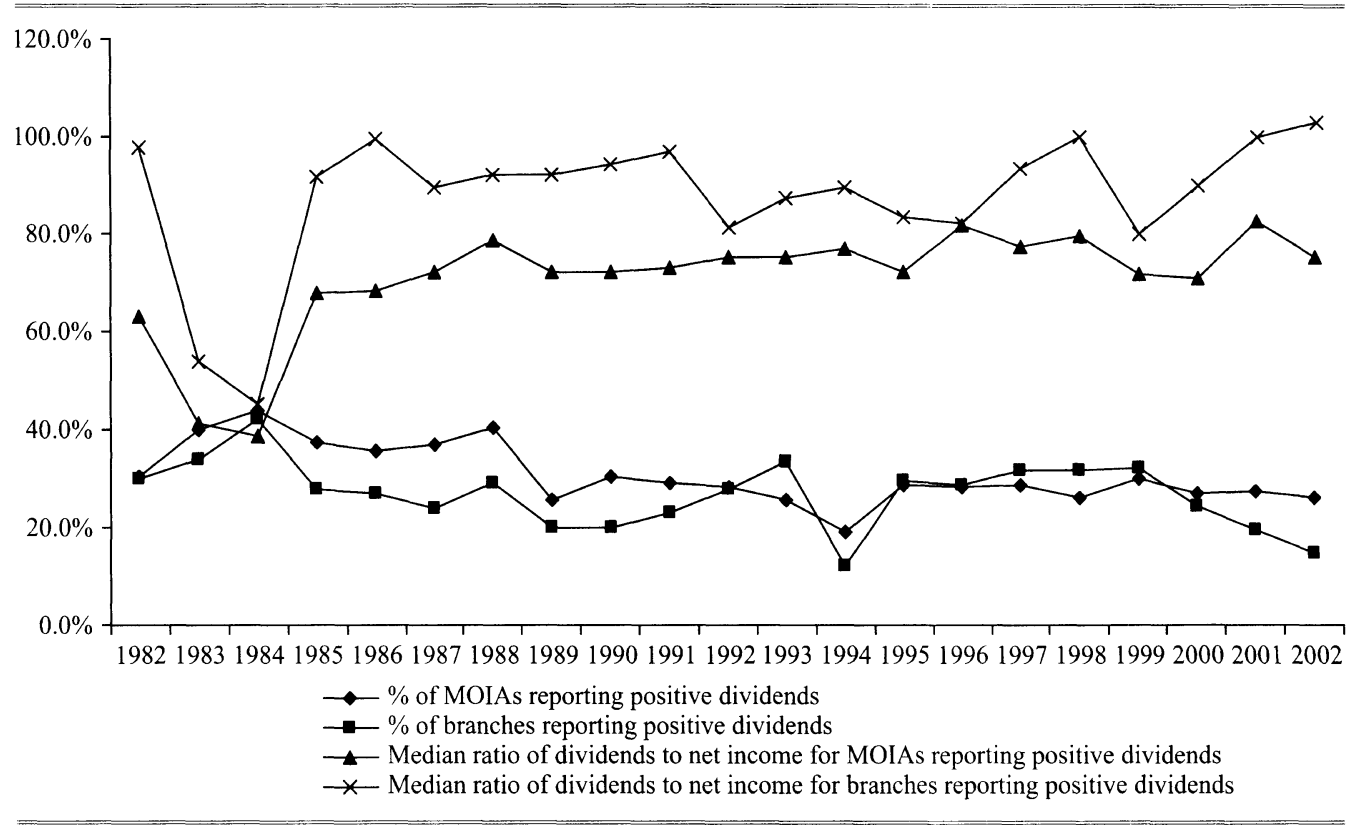

Figure 2. Persistence of Dividend Payments, 1983-2002

The line depicts the ratio of the number of entities that remit dividends in year $t$ to the number of entities that remit dividends in year $\mathrm{t}-1$ and that also report activity in year $\mathrm{t}$.

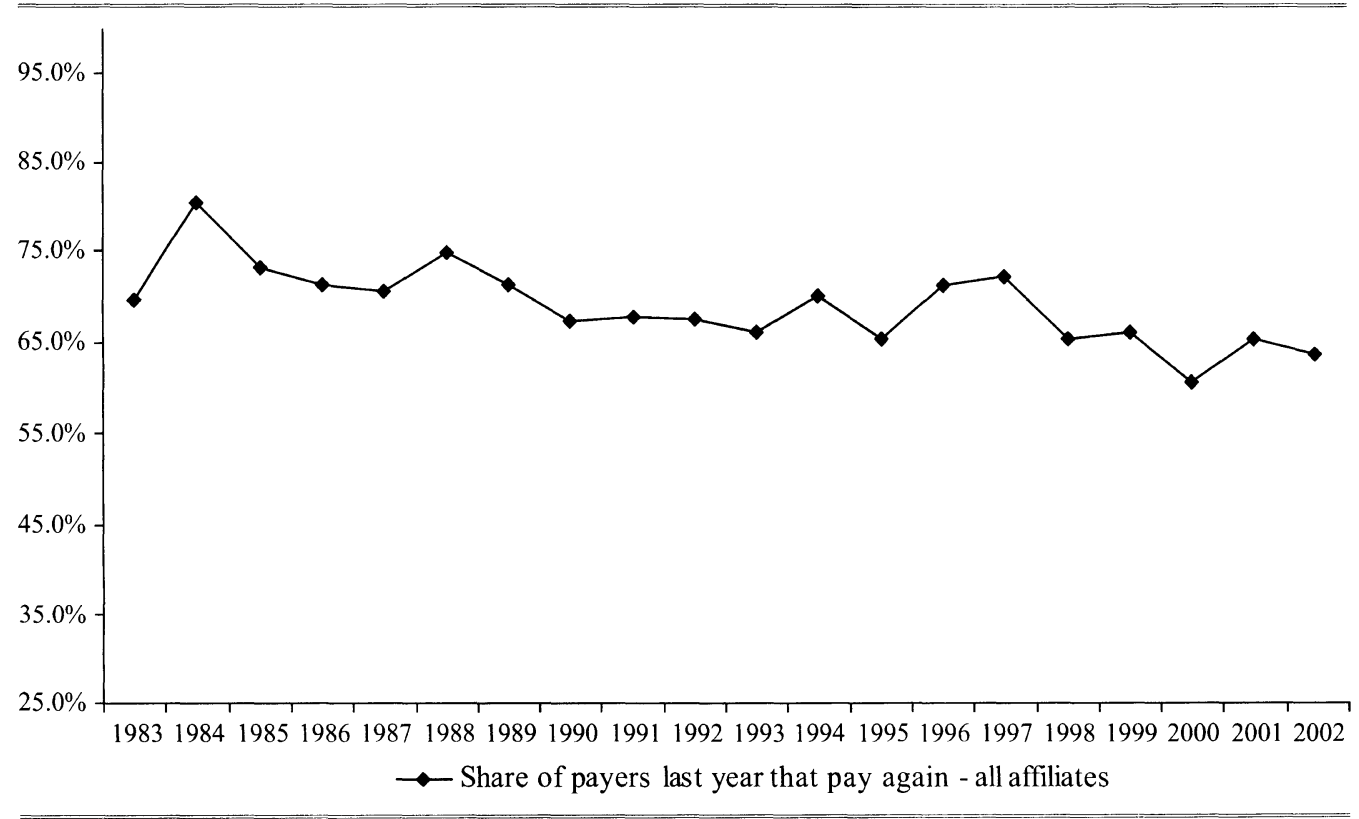




\section{Table I. Descriptive Statistics}

Panel A presents descriptive statistics for the affiliate-level panel of annual data from 1982 to 2002 that are analyzed in Tables II-V. Measures of dividends, net income and capital expenditures are in thousands of nominal U.S. dollars. Branch Dummy is equal to one for affiliates that are organized as branches, and Indirect Ownership Dummy is equal to one for separately incorporated affiliates for which the parent holds an indirect ownership claim. Parent Dividends to Shareholders Interacted with Relative Assets is the interaction of parent dividends to common shareholders as reported in Compustat and the ratio of affiliate assets to consolidated firm assets as reported in Compustat. Panel B presents descriptive statistics of parentlevel annual data used in the analysis presented in Table VI. Dividend payments by affiliates to parents and affiliate net income are aggregated across affiliates within parent systems. Panel C displays affiliate-level data that are studied in columns 1-3 of Table VII. The Percent of Affiliate Dividend Payments is computed across all years an affiliate appears in the sample. Measures of country tax rates and the log of GDP per capita are averages of these variables for a particular affiliate across years in which the affiliate appears in the sample. The Partial Ownership Dummy is equal to one if the affiliate is ever partially owned. Panel D presents sample statistics for the subsample of the sample described in Panel $\mathrm{C}$ for which parents increase their paid-in capital in the affiliate. Results of analyzing these data appear in columns 4-6 of Table VII.

Panel A. Affiliate-level Data for Tables II-V

\begin{tabular}{lccc}
\hline \hline & Mean & Median & Std. Dev. \\
\hline & & & \\
Dividend Payments by Affiliates to Parents & 6,677 & 0 & 47,127 \\
Net Income & 7,580 & 1,773 & 25,572 \\
Capital Expenditures & 9,064 & 985 & 41,192 \\
Branch Dummy & 0.0646 & 0.0000 & 0.2458 \\
Indirect Ownership Dummy & 0.1594 & 0.0000 & 0.3661 \\
Parent Dividends to Shareholders & 4,451 & 749 & 18,692 \\
$\quad$ Interacted with Relative Assets & & \\
\multicolumn{2}{c}{ Panel B. Parent-level Data for Table VI } \\
\hline Aggregate Dividend Payments & 39,308 & \\
$\quad$ by Affiliates to Parents & 58,534 & 0 & 227,059 \\
Aggregate Net Income & 0.5699 & 4,964 & 297,093 \\
Parent Leverage & 0.5555 & 0.2600 \\
\hline
\end{tabular}

Panel C. Affiliate-level Data for Columns 1-3, Table VII

\begin{tabular}{llll}
\hline Percent of Affiliate Dividend Payments that & & & \\
$\quad$ are Positive & 0.2880 & 0.2000 & 0.3054 \\
Country Tax Rate & 0.3277 & 0.3436 & 0.1176 \\
Partial Ownership Dummy & 0.1893 & 0.0000 & 0.3917 \\
Log of GDP Per Capita & 9.4158 & 9.8016 & 0.9382 \\
\hline
\end{tabular}

Panel D. Affiliate-level Data for Columns 4-6, Table VII

Dummy For Payment of Dividend by

$\begin{array}{llll}\text { Affiliates when Paid-in Capital Increases } & 0.2821 & 0.0000 & 0.4501\end{array}$

Country Tax Rate

$\begin{array}{lll}0.3328 & 0.3415 & 0.1141\end{array}$

$\begin{array}{llll}\text { Partial Ownership Dummy } & 0.1227 & 0.0000 & 0.3281\end{array}$

$\begin{array}{llll}\text { Log of GDP Per Capita } & 9.4077 & 9.7986 & 0.9409\end{array}$ 
The first step in identifying the dividend policies of foreign affiliates is to estimate the parameters associated with the Lintner framework. The essential features of the Lintner model are that tax and nontax variables determine both the target payout ratios and the rates at which actual dividends adjust to desired dividends. Thus, it is possible to generalize the Lintner framework by estimating the parameters of payout functions that differ between affiliates, based on observable characteristics of affiliates and parent companies. Extension of the framework demonstrates the extent to which tax motivations, domestic financing and investment needs, and control problems influence target payout ratios and rates of adjustment. ${ }^{6}$

\section{A. Payout Policies of Foreign Affiliates}

Table II displays the results of estimating a Lintner dividend equation for all majority-owned affiliates, assuming all affiliates have identical dividend payout equations. Since the Lintner specification includes lagged dividends as an explanatory variable, the 102,380 affiliate-year observations exclude those affiliates that appear only once in the sample, and the initial observations of all affiliates, including all 1982 observations.

The Lintner specification fits the data quite well. ${ }^{7}$ The estimated 0.2263 coefficient on lagged dividends in the regression reported in column 1 implies that affiliates pay dividends with adjustment parameters equal to $(1-0.23)$, or 0.77 . The affiliate's desired steady-state payout ratio is given by the ratio of the estimated coefficient on net income $(0.37)$ and the estimated adjustment parameter. In the case of the estimates reported in column one, the implied desired steady-state payout ratio is $(0.37 / 0.77)$, or $48 \%$.

This regression is repeated in columns 2 and 3, introducing fixed effects for parent firms and for affiliates, respectively, to control for unobservable characteristics that might influence dividend policy at the parent or affiliate level. Although the results with parent-firm fixed effects are not notably different from the results in column 1, including the affiliate fixed effects sharply reduces the magnitude of the estimated coefficient on lagged dividends, presumably by removing much of the variation in lagged dividends. Since the smaller magnitude is largely an artifact of the shortness of the panel, the subsequent analysis incorporates parent-firm, rather than affiliate, fixed effects. The Tobit specification of the basic Lintner regression equation presented in column 4 provides qualitatively similar results.

Dividend policy is one component of an overall financial policy that includes decisions about net borrowing, capital expenditures, and other sources and uses of funds. It is possible that foreign affiliates with attractive investment opportunities finance their new capital expenditures largely

\footnotetext{
${ }^{6}$ Early cross-sectional studies, such as Fama and Babiak (1968), report systematic differences between firms in the parameters of the Lintner functions that characterize their dividend payouts. Dewenter and Warther (1998) interpret differences in adjustment parameters as evidence of the impact of Japanese financial policies in their comparison of keiretsu and non-keiretsu firms. Fama and French (2002) use Lintner-like specifications to test the implications of the pecking order theory of capital structure. Table VII of Desai, Foley, and Hines (2002) presents results from estimating separate firm-specific Lintner parameters for each multinational group in the BEA panel, reporting findings that match those obtained from regressions in which each firm is restricted to having the same parameters (which vary according to observable firm characteristics).
}

${ }^{7}$ The basic Lintner specification in column (1) of Table 2 omits a constant term. In his original study of dividends, Lintner included a constant, but he examined the behavior of aggregate dividends, not dividends of individual firms. Subsequent research presents some evidence in favor of including a constant (see, for example, Choe (1990)) and some evidence in favor of suppressing it (see, for example, Fama and Babiak (1968)). The results presented here do not materially change if a constant is included. For an analysis of these data using a Lintner specification that includes a constant, see Desai, Foley, and Hines (2001). 
Table II. Lintner Dividend Specifications for Affiliate Payments to Parent Firms

The dependent variable in all specifications is the dollar value of dividend payments by majority-owned affiliates. Net Income is the after-foreign tax net income of the affiliate. Lagged Dividend Payments is the dollar value of dividend payments by the affiliate in the previous year. Column 1 presents an OLS specification without fixed effects. Column 2 presents an OLS specification with parent fixed effects. Column 3 presents an OLS specification with affiliate fixed effects. In columns 1 through 3 , heteroskedasticity-consistent standard errors are in parentheses. Column 4 presents a Tobit specification with standard errors presented in parentheses.

\begin{tabular}{lcccc}
\hline \hline & $\mathbf{( 1 )}$ & $\mathbf{( 2 )}$ & $\mathbf{( 3 )}$ & $\mathbf{( 4 )}$ \\
\hline Net Income & $0.3694^{* * *}$ & $0.3585^{* * *}$ & $0.3019^{* * *}$ & $0.2843^{* * *}$ \\
& $(0.0177)$ & $(0.0183)$ & $(0.0201)$ & $(0.0186)$ \\
Lagged Dividend Payments & $0.2263^{* * *}$ & $0.2139^{* * *}$ & $0.1136^{* * *}$ & $0.2267 * * *$ \\
& $(0.0328)$ & $(0.0334)$ & $(0.0359)$ & $(0.0339)$ \\
Fixed Effects? & No & Yes-Parent & Yes-Affiliate & No \\
OLS or Tobit? & OLS & OLS & OLS & Tobit \\
R- Squared & 0.3358 & 0.3236 & 0.4378 & \\
Log-Likelihood & & & & $-435,969$ \\
No. Obs & 102,380 & 102,380 & 102,380 & 102,380 \\
Payout Ratio & 0.48 & 0.46 & 0.34 & 0.37 \\
Adjustment Parameter & 0.77 & 0.79 & 0.89 & 0.77 \\
\hline
\end{tabular}

*** Significant at the 0.01 level.

by reducing or omitting dividends to parent companies. If so, and if capital expenditures are correlated over time, then the estimated dividend equations displayed in Table II and elsewhere might reflect the impact of changing investment patterns.

Table III presents the results of a number of regressions designed to explore this possibility. Columns 1 and 2 of Table III show the estimated coefficients for equations that are identical to those in columns 1 and 2 of Table II, except that in Table III affiliate capital expenditure is added as an explanatory variable. Including this variable has very little impact on the estimated net income and lagged dividend coefficients, which are almost identical to the values reported in Table II. Furthermore, the estimated effects of affiliate capital expenditures are positive in the regressions reported in columns 1 and 2 of Table III. These effects are inconsistent with a simple model in which dividend repatriations represent funds not used for foreign capital expenditures.

It is not necessary for foreign affiliates with attractive investment opportunities to reduce planned dividend payments to their American parent firms, since they can finance capital expenditures, as well as dividends, by net borrowing. Columns 3 through 6 of Table III report the results of the regressions where the sample of foreign affiliates is distinguished by the extent of local indebtedness. Affiliates with local debt/asset ratios that exceed median values for their industries are classified as having "high" local debt, while others are classified as having "low" local debt. Affiliates with high local debt/asset ratios may have the least ability to use capital markets to obtain additional financing for their activities, and therefore might exhibit the greatest impact of capital expenditures on dividends.

The results reported in columns 3 and 4 of Table III indicate that affiliates with considerable debt have dividend payout ratios that are higher and more sensitive to income than are the payout ratios of affiliates with little debt. The 0.3167 and 0.0943 coefficients in column 4 imply that heavily indebted affiliates increase their dividend repatriations by $\$ 0.41$ for every additional dollar of foreign income, whereas affiliates without heavy debt obligations increase their dividend 
Table III. Dividend Payments, Capital Expenditures, and Local Debt

The dependent variable in all specifications is the dollar value of dividend payments by majority-owned affiliates to parents. Net Income is the after-foreign tax net income of the affiliate. Lagged Dividend Payments is the dollar value of dividend payments by the affiliate in the previous year. Capital Expenditures is the dollar value of capital expenditures performed by the affiliate. The High Local Debt Dummy is computed by first calculating the ratio of an affiliate's local debt to its assets. An affiliate that has a ratio higher than the median in its industry in a particular year is assigned a value of one while an affiliate with a ratio below the median is assigned a value of zero. Columns 1,3 , and 5 present OLS specifications without fixed effects. Columns 2, 4, and 6 present OLS specifications with parent fixed effects. Heteroskedasticity-consistent standard errors are presented in parentheses.

\begin{tabular}{|c|c|c|c|c|c|c|}
\hline & (1) & (2) & (3) & (4) & (5) & (6) \\
\hline Net Income & $\begin{array}{l}0.3613 * * * \\
(0.0174)\end{array}$ & $\begin{array}{l}0.3523 * * * \\
(0.0181)\end{array}$ & $\begin{array}{l}0.3265^{* * *} \\
(0.0248)\end{array}$ & $\begin{array}{l}0.3167^{* * *} \\
(0.0256)\end{array}$ & $\begin{array}{l}0.3195^{* * *} \\
(0.0244)\end{array}$ & $\begin{array}{l}0.3115^{* * *} \\
(0.0253)\end{array}$ \\
\hline $\begin{array}{l}\text { Lagged Dividend } \\
\text { Payments }\end{array}$ & $\begin{array}{l}0.2232 * * * \\
(0.0330)\end{array}$ & $\begin{array}{l}0.2113 * * * \\
(0.0336)\end{array}$ & $\begin{array}{l}0.2232^{* * *} \\
(0.0535)\end{array}$ & $\begin{array}{l}0.2117 * * * \\
(0.0546)\end{array}$ & $\begin{array}{l}0.2212^{* * *} \\
(0.0538)\end{array}$ & $\begin{array}{l}0.2101^{* * *} \\
(0.0548)\end{array}$ \\
\hline Capital Expenditures & $\begin{array}{l}0.0207^{* *} \\
(0.0081)\end{array}$ & $\begin{array}{l}0.0192^{* *} \\
(0.0085)\end{array}$ & & & $\begin{array}{c}0.0203 \\
(0.0126)\end{array}$ & $\begin{array}{c}0.0182 \\
(0.0129)\end{array}$ \\
\hline $\begin{array}{l}\text { High Local Debt } \\
\text { Dummy Interacted } \\
\text { with Net Income }\end{array}$ & & & $\begin{array}{l}0.0979^{* * *} \\
(0.0354)\end{array}$ & $\begin{array}{l}0.0943 * * * \\
(0.0358)\end{array}$ & $\begin{array}{l}0.0975^{* * *} \\
(0.0351)\end{array}$ & $\begin{array}{l}0.0939^{* * *} \\
(0.0355)\end{array}$ \\
\hline $\begin{array}{l}\text { High Local Debt Dummy } \\
\text { Interacted with Lagged } \\
\text { Dividend Payments }\end{array}$ & & & $\begin{array}{c}0.0027 \\
(0.0641)\end{array}$ & $\begin{array}{c}0.0014 \\
(0.0643)\end{array}$ & $\begin{array}{c}0.0015 \\
(0.0644)\end{array}$ & $\begin{array}{c}0.0002 \\
(0.0646)\end{array}$ \\
\hline $\begin{array}{l}\text { High Local Debt Dummy } \\
\text { Interacted with Capital } \\
\text { Expenditures }\end{array}$ & & & & & $\begin{array}{l}-0.0043 \\
(0.0159)\end{array}$ & $\begin{array}{l}-0.0028 \\
(0.0160)\end{array}$ \\
\hline Parent Fixed Effects? & No & Yes & No & Yes & No & Yes \\
\hline R-Squared & 0.3364 & 0.3241 & 0.3392 & 0.3260 & 0.3397 & 0.3263 \\
\hline No. Obs & 101,913 & 101,913 & 98,272 & 98,272 & 97,805 & 97,805 \\
\hline
\end{tabular}

repatriations by $\$ 0.32$ for every additional dollar of foreign income. Including capital expenditures and their interaction with high local borrowing, in the regressions reported in columns 5 and 6 has very little effect on these results. The regression reported in column 6 of Table III indicates that once affiliate debt levels are taken into account, affiliate capital expenditures have statistically insignificant effects on dividend repatriations. In cases of heavily indebted affiliates, affiliate capital expenditures have slightly smaller effects on dividend repatriations than they do for other affiliates.

\section{B. Tax Motivations}

Since firms have incentives to organize internal fund transfers in tax-conscious ways, tax considerations are likely to influence dividend policies inside firms. The tax consequences of 
paying dividends are functions of affiliate organizational forms, whether parent companies own affiliates directly or indirectly, and local tax rates. The regressions reported in Table IV include interactions of net income and lagged dividends with dummy variables for branches and indirectly owned incorporated affiliates. These interaction terms identify the extent to which dividend payout behavior differs between affiliates with different organizational forms and, consequently, differing tax motivations. The regressions also measure the extent to which dividends from branch affiliates and indirectly owned affiliates are more or less sensitive to foreign tax rate differences than are dividends from directly owned subsidiaries.

Foreign tax rates are likely to have lesser effects on dividend repatriations from branch affiliates and indirectly owned affiliates than they are on dividend repatriations from directly owned subsidiaries. Dividend repatriations by foreign branches do not have US tax consequences, since the United States taxes foreign branch income independent of whether it is repatriated as dividends. Dividend payments from foreign affiliates that American companies own indirectly through other foreign affiliates will not trigger a home country tax liability unless the recipient resides in a jurisdiction that taxes foreign source income. Since many of the foreign affiliates of American corporations that are conduits for indirect ownership are located in countries that do not tax foreign income, it is unlikely that dividend payments from affiliates to indirect owners generate US tax liabilities. ${ }^{8}$

The results reported in column 1 of Table IV suggest that organizational form differences have only very minor implications for the general nature of dividend payout processes. ${ }^{9}$ The estimated 0.0425 coefficient on the interaction of the branch dummy variable and affiliate net income is positive but small and statistically insignificant. The estimated coefficient on the interaction of the branch dummy and lagged dividends is also insignificant. The estimated coefficients on variables that interact dummy variables for indirect ownership are likewise relatively small and insignificant. ${ }^{10}$ Thus the corresponding implied desired payout ratios and adjustment parameters for directly owned incorporated affiliates, branches, and indirectly owned affiliates are all very close to each other. This regression implies that affiliates with different forms of parent ownership and very different tax motivations exhibit similar dividend payout policies.

In Table IV, columns 3 and 5 repeat these regressions, but introduce fixed effects for parent firms and a Tobit specification of the regression equation in place of OLS. The results are similar to those reported in column 1 , in that coefficients on organizational form interactions remain insignificant.

\footnotetext{
${ }^{8}$ See Altshuler and Grubert (2003) and Desai, Foley, and Hines (2003).

${ }^{9}$ This exercise takes an affiliate's organizational form to be independent of its repatriation policy. Multinational firms choose whether to make their affiliates foreign branches or foreign subsidiaries; to the extent that these choices are dictated by anticipated future repatriation rates, then a comparison of repatriation rates between affiliates with different organizational forms will overstate the impact of tax rate differences. Other characteristics differ between branches and subsidiaries that could be correlated with tax rates and repatriation proclivities. Branch affiliates are concentrated in certain industries, including petroleum, wholesale trade, and services, though not entirely; in the 1997 sample, 26.4 $\%$ of branch affiliates were in non-petroleum manufacturing, compared with $52.1 \%$ of incorporated affiliates. While the geographic distribution of branches and subsidiaries was not identical, the median foreign tax rate paid by branch affiliates in 1997 was $30.4 \%$, compared to $31.1 \%$ for incorporated affiliates. Based on this information there is no strong reason to suspect that a comparison of the repatriation patterns of branches and subsidiaries would encounter difficulties due to spurious correlation with local tax rates.

${ }^{10} \mathrm{As}$ defined in these regressions, indirect ownership corresponds to zero direct ownership by the parent company. Changing the dummy variable to indicate any nonzero indirect ownership does not change the results.
} 


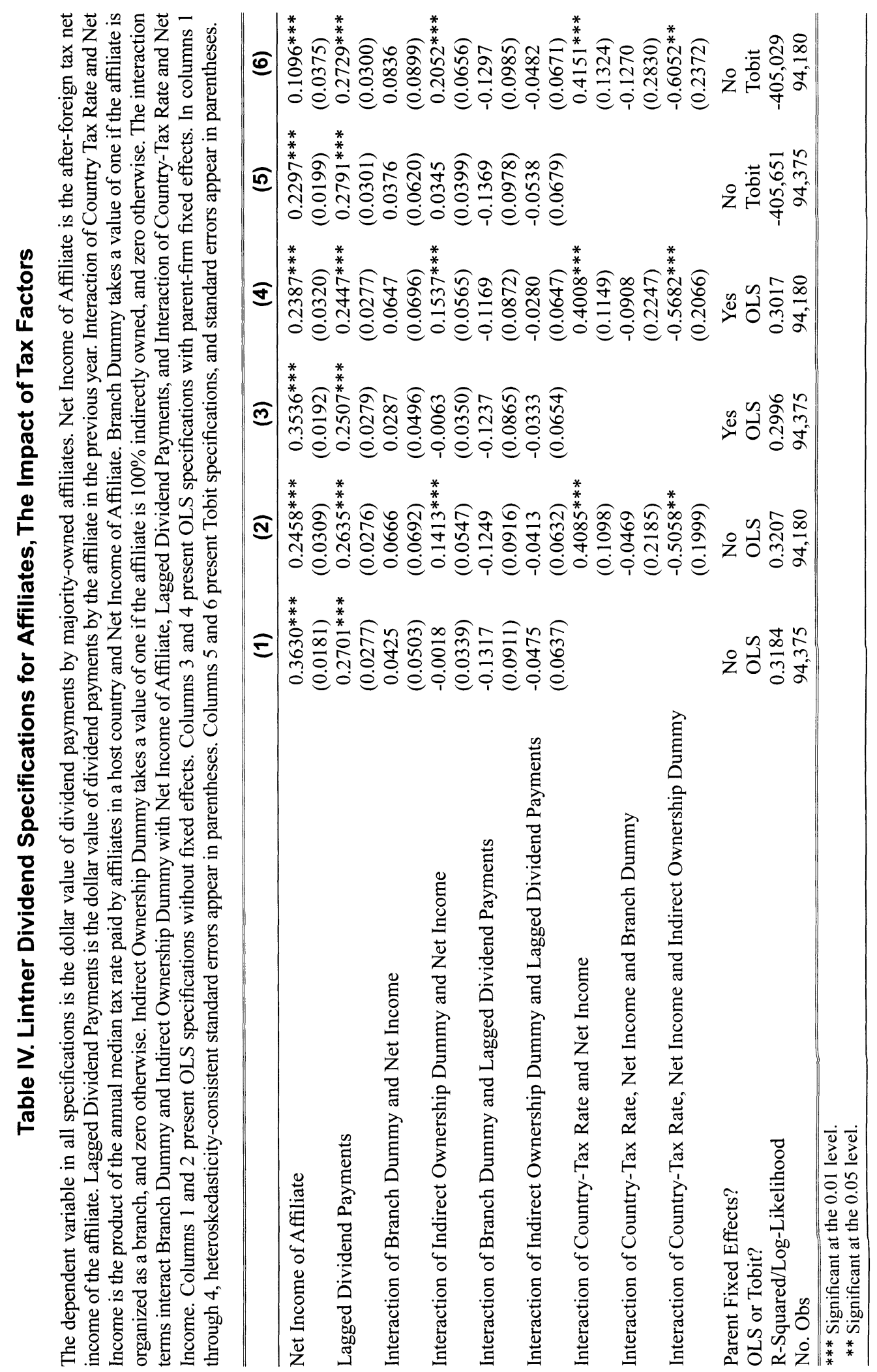


Investigating country-level variation in the tax cost of paying dividends provides a finer measure of the importance of tax motivations for affiliates. The regression reported in column 2 of Table IV includes country tax rates interacted with affiliate net income in addition to the variables used in the regressions reported in column 1. Country tax rates are measured by calculating ratios of foreign income taxes paid to the sum of foreign income taxes and net income for each affiliate observation. Medians of these rates are then used as country-level observations for each country and year. " For the purposes of calculating country tax rates, affiliates with negative net income are excluded. High foreign tax rates reduce the cost of paying dividends from directly held foreign subsidiaries to American parent companies, since doing so generates accompanying foreign tax credits that offset the associated US tax liability.

The results reported in column 2 of Table IV confirm that tax costs affect the long-run payout ratios of incorporated affiliates. The estimated 0.4085 coefficient on the interaction of country tax rates and net income reported in column 2 is both large and statistically significant, indicating that affiliates set higher payout ratios in countries where paying dividends generates larger foreign tax credits and therefore lower home country tax liabilities. ${ }^{12}$ Examining the value of the interaction of country tax rates and net income across organizational forms provides additional evidence of the impact of home country tax considerations on affiliate dividend payments. The estimated -0.5058 coefficient on the interaction of country tax rates, net income, and the indirect ownership dummy variable implies that tax rates do not influence payout ratios of indirectly owned affiliates. The sum of this coefficient and the coefficient on the country tax rate interacted with net income is -0.0973 , and it does not differ significantly from zero. This result is consistent with the tax incentives facing indirectly owned affiliates, and the way in which they differ from the incentives of separately incorporated affiliates. The estimated -0.0469 coefficient on the interaction of country tax rates, net income, and the branch dummy indicates that tax effects on repatriations are also mitigated in the case of foreign branches, which is consistent with their incentives. Including parent-firm fixed effects in column 4 and using a Tobit specification in column 6 produces similar results. ${ }^{13}$ In these specifications, the payout ratios of branches and the indirectly owned affiliates do not vary with tax rates in a statistically significant way.

The evidence indicates that incorporated affiliates adjust long-run payout ratios to reflect tax costs. The absence of such effects on the payout ratios of branches and indirectly owned affiliates is consistent with the importance of tax motivations. Nonetheless, the similarity of the dividend policies of affiliates with different organizational forms, and thus different tax treatments, indicates that tax motivations do not fully account for patterns of dividend policies inside firms. ${ }^{14}$

\footnotetext{
"Affiliates with negative net income are excluded for the purposes of calculating country tax rates. Desai, Foley, and Hines (2001) provide a complete description of the properties of country tax rates and alternative methods of their calculation.

${ }^{12}$ The US Tax Reform Act of 1986 changed the way in which foreign tax credits were calculated, as a result of which, firms faced stronger incentives to adjust their dividend repatriations in response to transitory tax rate changes before 1986 than they did after 1986. Additional regressions (available from the authors) indicate that repatriations responded more sharply to tax differences in the years before 1986 than they did after 1986.

${ }^{13}$ Desai, Foley, and Hines (2001) note that tax incentives may vary between affiliates located in the same country. Incorporating this variation, along with instrumenting for the affiliate tax rate with a country tax rate, provides an additional test of the tax motivations of dividend policy inside the firm - although the results are largely unchanged.

${ }^{14}$ Some countries also impose small withholding taxes on repatriations from foreign subsidiaries and foreign branches. Using the BEA data to measure the magnitude of these withholding tax rates, and adding withholding taxes as separate independent variables, produces results (available from the authors) that indicate that withholding taxes discourage repatriations, though the effects of other variables closely resemble those reported in the paper.
} 


\section{Parent Company Cash Needs}

One straightforward explanation for the presence of Lintner-like patterns inside the firm is that the demands of the many and varied shareholders in public capital markets translate into demands for dividend repatriations inside the firm. Parent firms that feel obligated to pay dividends to common shareholders might draw on financial resources available in foreign affiliates, thereby triggering dividend repatriations. In view of the widely documented tendency to pay greater dividends out of $\$ 1$ of foreign earnings than $\$ 1$ of domestic earnings, this process is likely to be strongest in cases of firms with significant foreign earnings. ${ }^{15}$ Another possibility is that parent companies with attractive domestic investment opportunities draw on the resources of their foreign affiliates, and these resource flows take the form of dividend repatriations.

Figure 3 illustrates these possibilities. The heights of the bars in the figure measure the fraction of domestic parent companies that receive nonzero dividends from their foreign affiliates, grouping parent firms into terciles in two different ways. The left-hand bar provided for each tercile gives information for firms characterized by the ratio of parent payouts to common external shareholders to parent domestic after-tax earnings. The right-hand bar for each tercile presents information for firms characterized by the attractiveness of domestic investment opportunities, which are measured by Tobin's $q$, higher values of $q$ corresponding to greater desired investment. ${ }^{16}$ Figure 3 shows that the parent companies with the highest dividend payout ratios are the most likely to receive dividend repatriations from their foreign affiliates. Greater investment opportunities are also associated with a higher likelihood of repatriation from foreign affiliates, which again suggests that parent companies use repatriations to satisfy their cash needs. Since the patterns presented in Figure 3 do not control for affiliate profitability and other characteristics that are likely to influence repatriations, to identify more precisely the impact of cash demand by parent companies it is necessary to include these characteristics as independent variables.

Comparing the dividend policies of affiliates whose parents have different degrees of exposure to public capital markets tests the hypothesis that needs for domestic financial resources to pay dividends to common shareholders are strong enough to drive repatriation policies. Table $\mathrm{V}$ reports the results of affiliate payout regressions that take explicit account of the ownership of parents companies, and, in the case of publicly held companies, their dividend policies. The dependent variable in the regressions in Table $\mathrm{V}$ is dividend repatriations from affiliates to their parents. To capture those affiliates that do not face the demands of public shareholders, Column 1 of Table $\mathrm{V}$ is limited to the sample of affiliates whose parents do not appear in Compustat. ${ }^{17}$ The implied desired steady-state payout ratios $(0.39)$ and adjustment parameters $(0.80)$ of affiliates of these private firms are similar to the desired payout ratios $(0.51)$ and adjustment parameters (0.74) of affiliates whose parents are listed in Compustat, as reported in column 2. Since firms

\footnotetext{
${ }^{15}$ See Hines (1996), who reports that $\$ 1$ of foreign profitability has 3-4 times the effect on dividend payments to common shareholders than does $\$ 1$ of domestic profitability. Hines attributes the difference to the use of dividends to signal profitability, which may be more difficult for the market to verify in the case of foreign earnings; Bodnar and Weintrop (1997) attribute the same phenomenon to the greater growth prospects of foreign earnings.
${ }^{16}$ Values of $q$ are measured as the ratio of the book value of assets plus the difference of market and book values of equity to the book value of assets. These firm-level $q$ 's are categorized into three-digit BEA industry categories, and the median firm value of $q$ within an industry is the industry level $q$. Firm-level regressions (not reported) of domestic investment on this measure of $q$ provide a positive and significant coefficient on $q$.

${ }^{17}$ While it is possible that such non-Compustat firms are not privately held but are instead foreign-based and therefore not listed on an American exchange, manual inspection of the data suggest that this is rarely the case.
} 
Figure 3. Repatriation Policies and Parent-Firm Financing Needs

Figure 3 shows the share of parent firms that receive dividends from affiliates within terciles. The left column for each tercile corresponds to a grouping of firms based on the ratio of parent dividends to shareholders to parent net income. The right column for each tercile corresponds to a grouping of firms based on parent-firm industry $q$.

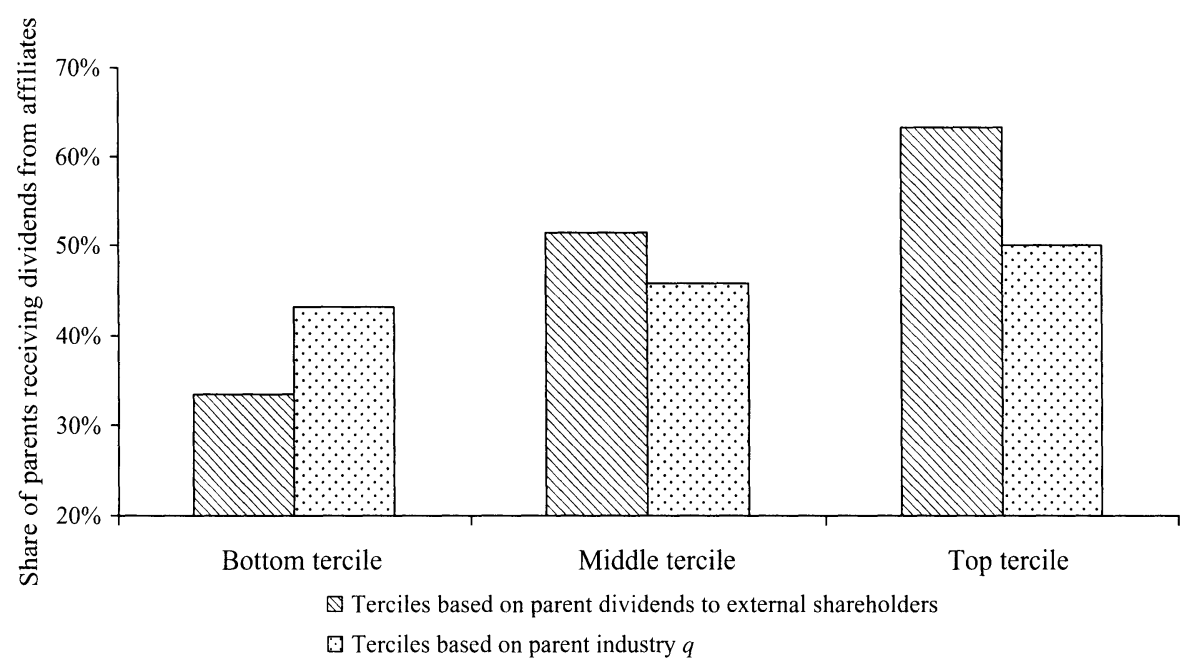

that are not publicly traded presumably face little capital market pressure to pay dividends to their owners, but nevertheless exhibit similar behavioral patterns, this comparison suggests that capital market pressures are unlikely to account for estimated affiliate payout equations. The similarity of the dividend policies of the foreign affiliates of private and public parents persists when parent-firm fixed effects are included, as reported in columns 4 and 5 of Table $\mathrm{V}$, and in the Tobit specifications reported in columns 7 and 8 .

Columns 3, 6, and 9 of Table $\mathrm{V}$ report the estimated coefficients from payout equations for affiliates of Compustat firms. These columns include a variable intended to capture parental financial pressure stemming from financial flows to common shareholders as an independent variable. The variable "Parent Dividends to Shareholders Interacted with Relative Assets" is the product of parent-firm dividends and the ratio of affiliate assets to total firm assets. If parent firms finance dividends to shareholders with funds drawn from all parts of the firm in proportion to assets, then an affiliate should be expected to remit a dividend to its parent firm that is equal to the value of this variable. Hence, if parent-firm pressures determine repatriation policies in this manner, the estimated coefficient on this variable would be close to unity.

The estimated coefficients on "Parent Dividends to Shareholders Interacted with Relative Assets" in the OLS specifications equal roughly 0.14 , thus differing significantly from one at the $5 \%$ level. As measured by dividends to common shareholders, parent-firm financial pressures explain some, but only a modest portion, of affiliate dividend payouts. In addition, the estimates of desired steady-state payout ratios and adjustment parameters are not significantly affected by including the "parent dividends" variable on the right-hand side. The OLS results reported in columns 3 and 6 of Table $V$ differ somewhat from the Tobit results reported in column 9 , since the estimated coefficients from the Tobit specification suggest that affiliate dividends are higher when parent-firm dividends are smaller. Taken together, the results in Table V indicate that 


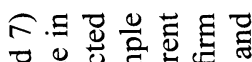

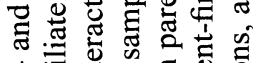

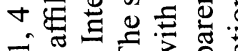

的 $\mathrm{F}$ 员

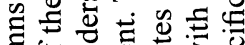

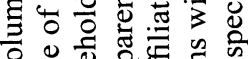

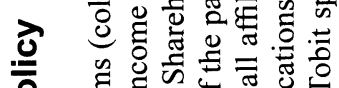

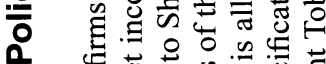

0 $\quad \begin{aligned} & 0 \\ & 0\end{aligned}$

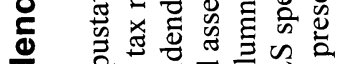

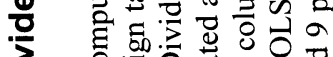

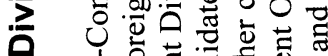

o

๘

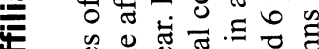

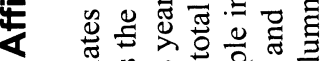

ธ

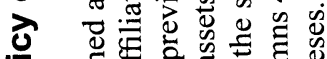

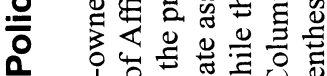

Q

응 है

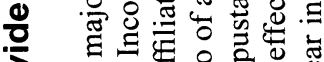

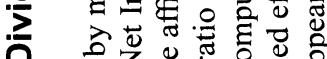

0 है

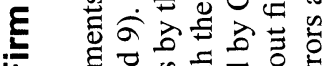

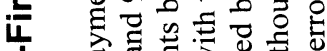

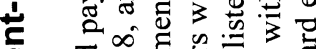

屯

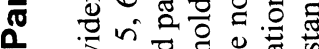

ठ

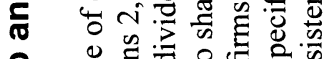

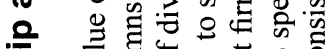

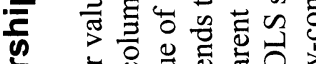

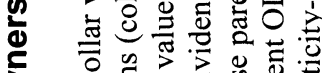

ร के है

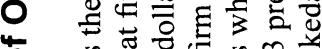

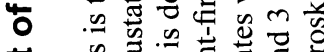

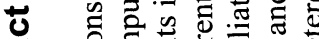

๙

E

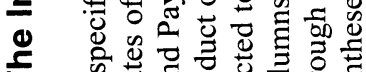

₹ $\quad$ की

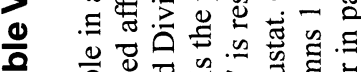

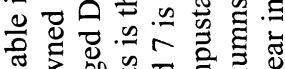

爱

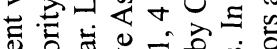

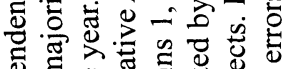
むั

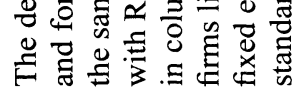

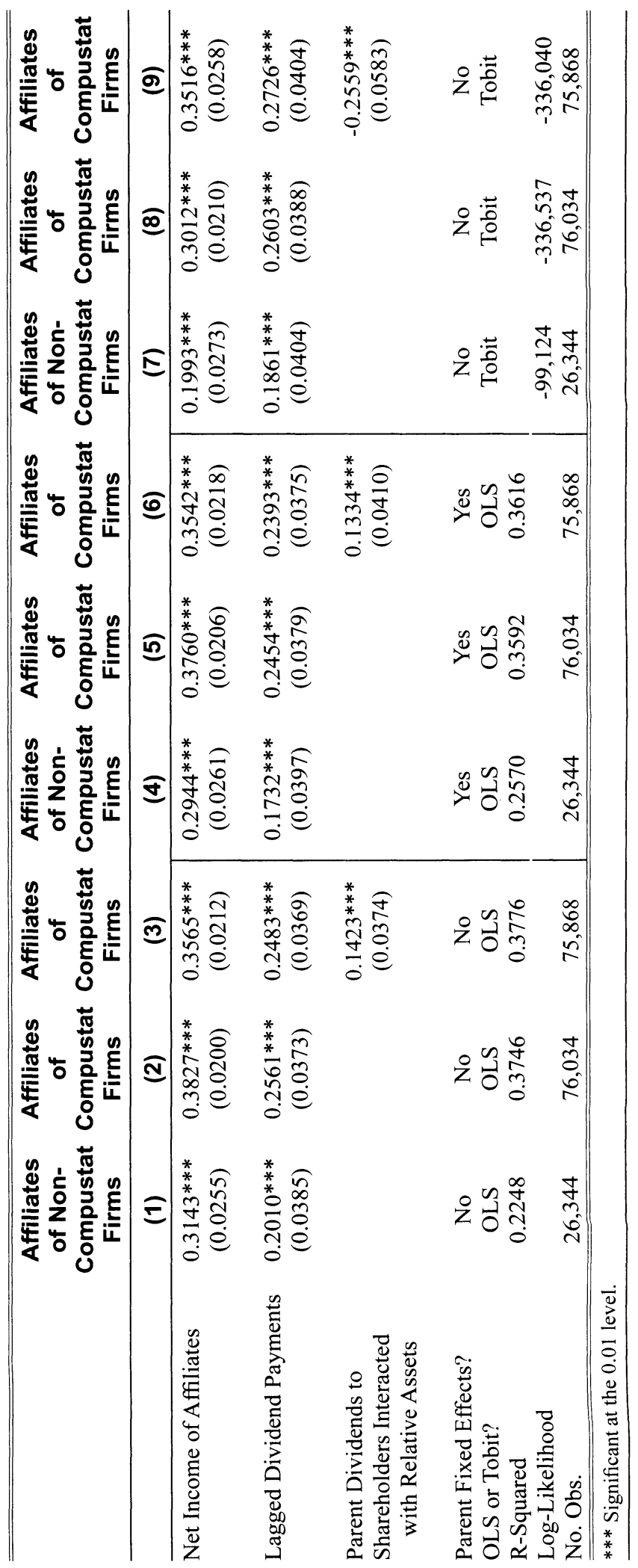


the dividend policies of affiliates of privately owned parents are similar to the dividend policies of affiliates whose parent firms are publicly owned. ${ }^{18}$

Multinational firms that wish to expand domestic investment are able to draw on the resources of their foreign affiliates. In turn, these financing needs might dictate repatriation policies, particularly if parent firms are otherwise financially constrained. To evaluate this possibility, it is useful to examine how repatriation policies vary as a function of domestic investment opportunities and limited access to additional external investment funds. Highly leveraged firms have been emphasized in previous studies of the role of financing constraints in limiting investment responses to profitable opportunities. ${ }^{19}$ Accordingly, the regressions in Table VI analyze whether highly levered parent firms repatriate funds from their foreign affiliates when facing attractive domestic investment opportunities, and measure the extent to which such repatriations account for the regular patterns of payout policy.

The dependent variable in the regressions reported in Table VI is total repatriations received by parent companies from all of their foreign affiliates. Since these regressions consider the impact of financing needs at the parent-company level, the unit of observation is a parent-year cell. Column 1 of Table VI reports a regression that is an aggregated (at the parent-firm level) version of the regression reported in column 2 of Table II, with a similar estimated coefficient on net income and a somewhat larger coefficient on lagged dividends. The regression reported in column 2 of Table VI adds an interaction between affiliate income and parent-firm leverage, where parent-firm leverage is defined as the ratio of total domestic liabilities to total domestic assets reported to the BEA. The estimated coefficients on aggregate affiliate net income and aggregate lagged dividends reported in column 2 imply that parent firms with zero leverage have a target payout ratio of $50.8 \%$, in contrast to the implied target payout ratio from column 1 of $61.1 \%$. The coefficients in column 2 also imply that target payout ratios are a function of leverage, as firms with leverage ratios of one have target payout ratios of $70.9 \% .{ }^{20}$

In evaluating whether financially constrained firms deploy foreign resources to finance domestic investment, it is useful to consider the combined impact of leverage and current investment opportunities. The regressions in columns 3 and 4 are estimated on separate samples. The observations in column 3 consist of firms with domestic activity primarily classified in three-digit industry-year cells with above-median values of Tobin's $q$. The observations in column 4 comprise firms with domestic activity primarily classified in industry-year cells with below-median values of Tobin's $q$. The estimated impact of parent leverage differs sharply between these two samples. The -0.0236 coefficient in column 3 suggests that greater parent-firm leverage slightly reduces the effect of foreign income on repatriations by affiliates of parent companies in industries with low $q$ 's, but the 0.1208 coefficient in column 4 implies that greater leverage is associated with significantly greater repatriations by firms in industries with high $q$ 's. ${ }^{21}$

\footnotetext{
${ }^{18}$ Desai, Foley, and Hines (2002) report similar patterns in their analysis of the impact of ownership transitions, as when private firms are taken public and publicly owned firms are taken private in leveraged buyouts. Neither type of ownership transition appears to be associated with significant changes in dividend policies.

${ }^{19}$ See, for example, Lang, Ofek and Stulz (1996).

${ }^{20}$ The $70.9 \%$ target payout ratio is calculated as $(0.2729+0.1074) /(1-0.4633)$. A comparison of leverage ratios from zero to one encompasses $95 \%$ of the sample.

${ }^{21}$ The $q$ measure of investment opportunities is derived from firm-level data and, as a consequence, captures firm worldwide investment opportunities rather than merely domestic investment opportunities. Since the majority of investment and business activity by American firms is domestic, it follows that measured $q$ primarily reflects domestic opportunities, but it is possible that high values of $q$ could be associated with greater desired foreign investment, which would reduce the incentive to repatriate funds from abroad, and reduce the effect of investment opportunities on repatriations as measured in TableVI.
} 


\section{Table VI. Lintner Dividend Specifications for Aggregate Affiliate Payments to} Parent Firms

The dependent variable in all specifications is the dollar value of dividend payments by majority-owned affiliates aggregated across affiliates in a parent-firm system. Aggregate Net Income is the aggregated afterforeign tax net income of affiliates within a parent-firm system. Parent Leverage is the ratio of parent-firm domestic current liabilities and long term debt to parent-firm domestic assets. Aggregate Lagged Dividend Payments is the aggregated dollar value of dividend payments by affiliates within a parent-firm system in the previous year. All of the specifications are OLS specifications with parent-firm fixed effects. The sample in the first two columns includes all parent firms in all years. Columns 3 and 4 split the sample into subsamples depending on whether a parent firm's industry $q$ is below or above the sample median, respectively. Heteroskedasticity-consistent standard errors appear in parentheses.

\begin{tabular}{lcccc}
\hline \hline Sample & \multicolumn{2}{c}{ Full Sample } & Low q Sample & High q Sample \\
\hline & $\mathbf{( 1 )}$ & $\mathbf{( 2 )}$ & $\mathbf{( 3 )}$ & $\mathbf{( 4 )}$ \\
\hline Aggregate Net Income & $0.3260^{* * *}$ & $0.2729^{* * *}$ & $0.4555^{* * *}$ & $0.1989^{* * *}$ \\
& $(0.0046)$ & $(0.0101)$ & $(0.0168)$ & $(0.0148)$ \\
Interaction of Aggregate Net & & $0.1074^{* * *}$ & -0.0236 & $0.1208^{* * *}$ \\
$\quad$ Income and Parent Leverage & & $(0.0181)$ & $(0.0290)$ & $(0.0274)$ \\
Aggregate Lagged Dividend & $0.4662^{* * *}$ & $0.4633^{* * *}$ & $0.1817^{* * *}$ & $0.6312^{* * *}$ \\
$\quad$ Payments & $(0.0064)$ & $(0.0065)$ & $(0.0079)$ & $(0.0105)$ \\
Parent Fixed Effects? & Yes & Yes & Yes & Yes \\
R- Squared & 0.8304 & 0.8307 & 0.8891 & 0.8246 \\
No. Obs & 17,747 & 17,310 & 8,355 & 8,365 \\
\hline \hline
\end{tabular}

*** Significant at the 0.01 level.

The evidence in Table VI indicates that the combination of high leverage and significant investment opportunities motivates firms to increase target payout ratios for their foreign affiliates. Although the regressions reported in Table VI provide evidence that foreign earnings are an important source of finance for domestic investment, these results also indicate that the Lintner process that characterizes dividend repatriations is not a manifestation of this financing channel alone. The coefficients in columns 3 and 4 indicate that firms with no leverage and above-average investment opportunities still pursue Lintner-like policies, as do firms with below-average investment opportunities regardless of their leverage. Consequently it is necessary to entertain additional explanations for the determinants of dividends inside the firm.

\section{Dividends and Incomplete Ownership}

Incomplete ownership of foreign affiliates reduces the ability of parent companies to monitor and control foreign managers. Partial ownership of foreign affiliates by local firms in host countries increases the risk that a manager will pursue related-party transactions that are not in the interest of the multinational parents. In such a setting, a rigid repatriation policy may help to control foreign management by limiting its financial discretion.

This section studies the extent to which multinationals use regular dividend payments to mitigate problems arising from incomplete ownership. In order to do so, the regularity of dividends is measured by calculating the fraction of years in which dividends are paid by affiliates that appear in the sample at least five times. The first three regressions in Table VII report the 


\section{Table VII. Dividends and Partial Ownership}

The sample in columns 1-3 consists of all affiliates that report dividends five or more times. The dependent variable in columns 1-3 is the share of reported dividend payments that are positive. In columns 1-3, Country Tax Rate is the median tax rate in the country in which an affiliate is located averaged over all years that affiliate appears in the sample. Partial Ownership Dummy takes the value of one if the affiliate is not wholly owned in any of the years the affiliate appears in the sample. Log of GDP Per Capita is the log value of GDP per capita averaged over all years the affiliate appears in the sample. The sample in columns 4-6 consists of those affiliate-years where a parent increases the paid-in-capital of the affiliate. The dependent variable in columns 4-6 is a dummy that takes the value one if the affiliate pays a dividend in that year, and zero otherwise. In columns 4-6, time-varying measures of the independent variables are used. Heteroskedasticityconsistent standard errors appear in parentheses.

\begin{tabular}{|c|c|c|c|c|c|c|}
\hline \multirow[t]{2}{*}{$\begin{array}{l}\text { Dependent } \\
\text { Variable }\end{array}$} & \multicolumn{3}{|c|}{$\begin{array}{l}\text { Percent of Affiliate Dividend } \\
\text { Payments that are Positive }\end{array}$} & \multicolumn{3}{|c|}{$\begin{array}{l}\text { Dummy For Payment of Dividend } \\
\text { by Affiliates when Paid-in Capital } \\
\text { Increases }\end{array}$} \\
\hline & (1) & (2) & (3) & (4) & (5) & (6) \\
\hline Constant & $\begin{array}{c}0.2695^{* * * *} \\
(0.0090)\end{array}$ & $\begin{array}{c}0.2551^{* * * *} \\
(0.0091)\end{array}$ & $\begin{array}{c}0.5385^{* * *} \\
(0.0342)\end{array}$ & $\begin{array}{c}-0.7453 * * * \\
(0.0390)\end{array}$ & $\begin{array}{c}-0.8023 * * * \\
(0.0393)\end{array}$ & $\begin{array}{l}-0.2011 \\
(0.1267)\end{array}$ \\
\hline Country Tax Rate & $\begin{array}{l}0.0566^{* *} \\
(0.0262)\end{array}$ & $\begin{array}{l}0.0465^{*} \\
(0.0260)\end{array}$ & $\begin{array}{c}0.0767 * * * \\
(0.0296)\end{array}$ & $\begin{array}{c}0.5093 * * * \\
(0.1102)\end{array}$ & $\begin{array}{c}0.4836^{* * *} \\
(0.1100)\end{array}$ & $\begin{array}{c}0.6394 * * * \\
(0.1201)\end{array}$ \\
\hline Partial Ownership & & $0.0934 * * *$ & $0.0851^{* * *}$ & & $0.4861 * * *$ & $0.4489 * * *$ \\
\hline Dummy & & $(0.0083)$ & $(0.0084)$ & & $(0.0352)$ & $(0.0365)$ \\
\hline $\begin{array}{l}\text { Log of GDP Per } \\
\text { Capita }\end{array}$ & & & $\begin{array}{c}-0.0310 * * * \\
(0.0036)\end{array}$ & & & $\begin{array}{c}-0.0695 * * * \\
(0.0137)\end{array}$ \\
\hline No. Obs. & 10,513 & 10,513 & 10,162 & 12,090 & 12,090 & 11,825 \\
\hline Log-Likelihood & & & & $-7,188$ & $-7,094$ & $-6,748$ \\
\hline R-squared & 0.0005 & 0.0148 & 0.0236 & & & \\
\hline $\begin{array}{l}* * * \text { Significant at the } \\
* * \text { Significant at the } \\
* \text { Significant at the }\end{array}$ & $\begin{array}{l}1 \text { level. } \\
5 \text { level. } \\
0 \text { level. }\end{array}$ & & & & & \\
\hline
\end{tabular}

coefficient estimates using this dependent variable. The positive estimated coefficients on the country tax rate variable across the specifications presented in columns 1 through 3 are consistent with the tax incentives that affiliates face, since higher foreign tax rates reduce US obligations upon repatriation. ${ }^{22}$

Columns 2 and 3 of Table VII add a partial ownership dummy that equals one if the American parent owns less than $100 \%$ of an affiliate, and zero otherwise..$^{23}$ The results reported in columns 2 and 3 indicate that partially owned affiliates pay dividends most frequently. The estimated coefficients imply that partially owned affiliates pay dividends in $9 \%$ more years than do wholly owned affiliates.

One of the strong implications of the US tax treatment of foreign income is that American multinational corporations should not simultaneously remit dividends from low-tax foreign

\footnotetext{
${ }^{22}$ In these specifications, tax rates are averaged across all years for which the affiliate is in the sample. As a consequence, measurement of relative tax incentives is somewhat noisy.

${ }^{23} \mathrm{All}$ affiliates in the sample are majorit - wned, so partial ownership is defined as more than $50 \%$ but less than $100 \%$ ownership.
} 
Figure 4. Propensity to Pay Dividends, by Changes in Paid-In-Capital (PIC), 1983-2002

Figure 4 tracks the share of dividend payers for three subsets of majority-owned incorporated affiliates: (i) those experiencing increases of PIC $>5 \%$; (ii) those experiencing decreases of PIC $>5 \%$; and (iii) all others.

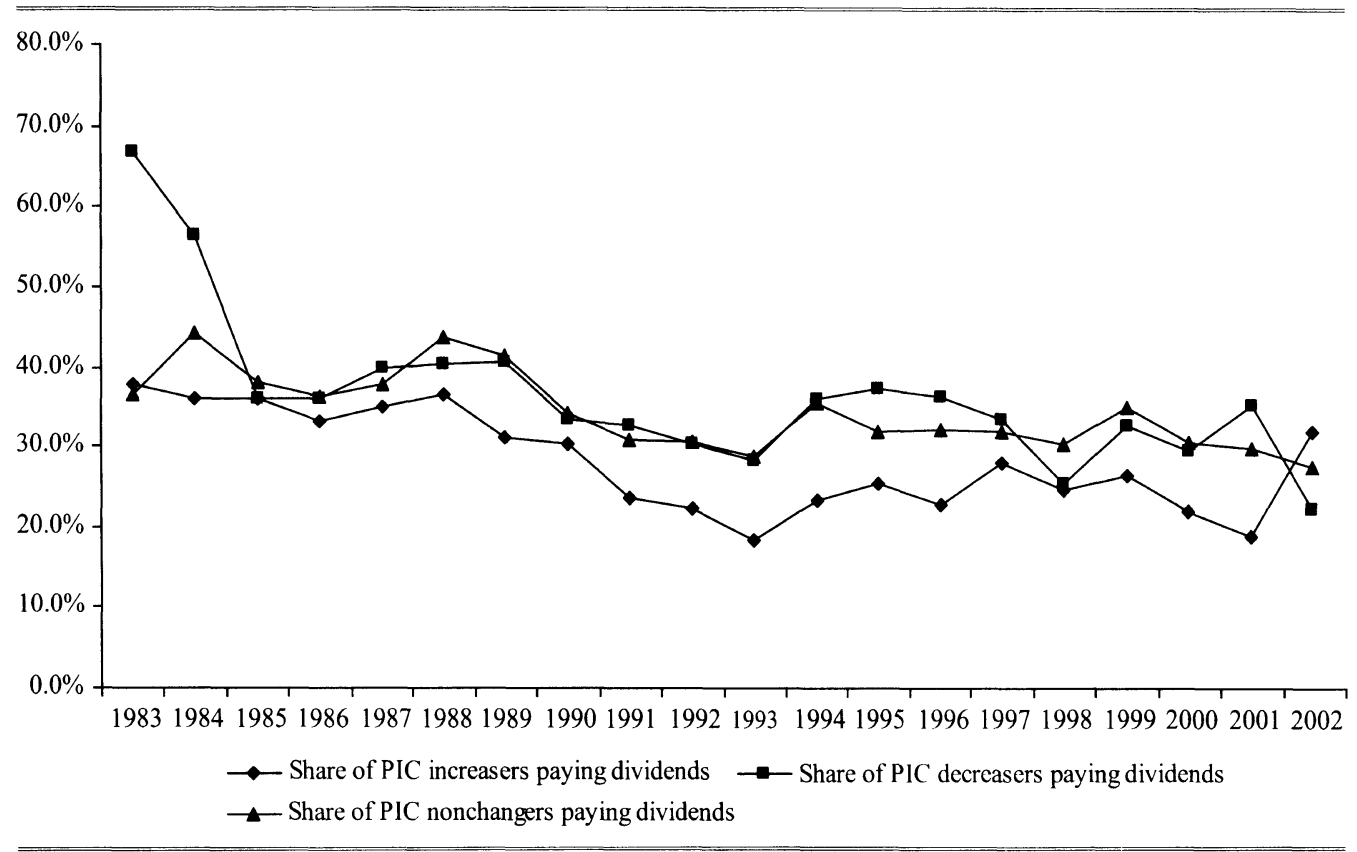

locations and transfer equity funds into the same foreign locations. Doing so generates a homecountry tax liability that could be easily avoided simply by reducing both dividends and equity transfers. Nevertheless, the data indicate that American multinational firms engage in this taxpenalized behavior.

Figure 4 shows that the likelihood of paying a dividend is the same across the sample period, regardless of the contemporaneous change in paid-in-capital. The regressions presented in columns 4 through 6 of Table VII show the determinants of tax-penalized behavior, thus testing whether this behavior is driven by situations in which parent firms impose rigid repatriation policies in reaction to partial ownership of affiliates.

Columns 4 through 6 of Table VII report the regressions run on the sample of affiliate-years for which parent companies increased paid-in affiliate capital. The table reports estimated coefficients from Probit specifications in which the dependent variable equals one if the affiliate paid a nonzero dividend to its parent and zero otherwise. The large positive estimated coefficients on the country tax rate variable indicate that affiliates in high tax rate countries are the most likely to pay dividends while receiving equity transfers from their parents, which is consistent with their tax incentives. Parent firms without excess foreign tax credits that have affiliates located in countries with high tax rates can find it advantageous to remit dividends while simultaneously transferring equity funds from the parent, since doing so generates foreign tax credits that can profitably be used to reduce tax burdens on other income. The positive coefficients on the partial ownership dummy variable support the results reported in columns 2 and 3 indicating that parent companies require partially owned affiliates to pay regular dividends. The estimates from column 5 imply that the effect of partial ownership is similar to the effect of a $100 \%$ higher tax rate. The dividend behavior of partially owned affiliates differs significantly from that of affiliates that are wholly owned by their parents. 


\section{Conclusion}

The foreign affiliates of American multinational corporations follow well-defined repatriation policies that entail the gradual adjustment of payouts in the direction of targets that depend on current earnings and the tax costs of repatriating dividends. Although repatriation policies are responsive to tax factors, the similarity of dividend policies across entities that have distinctive tax treatments indicates that tax motivations alone cannot explain the patterns of behavior. Repatriations help parent firms meet their financing needs, since larger dividends to external shareholders are associated with larger dividend repatriations inside the firm. Furthermore, highly levered parent companies with profitable domestic investment opportunities draw more heavily on the resources of their foreign affiliates. The analysis of explicitly tax-penalized behavior and regularized repatriation policies suggests that shared ownership of foreign affiliates contributes substantially to the routinization of repatriation policy inside the firm.

What Black (1976) christened the "dividend puzzle" - the problem of reconciling observed dividend behavior with economic incentives facing the relevant decision makers - is typically cast as a result of the relationship between external shareholders and internal corporate managers. Repatriation policy inside the firm is subject to many, but not all, of the same pressures, as are the dividend policies of firms with public ownership. The results in this paper indicate that the factors that govern repatriation policies inside the firm - tax factors, costly external finance at the parent level, and agency concerns with the firms - are those that scholars emphasize in attempting to resolve the dividend puzzle more generally.

\section{References}

Altshuler, R. and H. Grubert, 2003, "Repatriation Taxes, Repatriation Strategies and Multinational Financial Policy," Journal of Public Economics 87, 73-107.

Altshuler, R., T.S. Newlon, and W.C. Randolph, 1995, "Do Repatriation Taxes Matter? Evidence from the Tax Returns of US Multinationals," in M. Feldstein, J.R. Hines Jr., and R.G. Hubbard, Eds., The Effects of Taxation on Multinational Corporation, Chicago, IL, University of Chicago Press, 253-272.

Benartzi, S., R. Michaely, and R. Thaler, 1997, "Do Changes in Dividends Signal the Future or the Past?" Journal of Finance 52, 1007-1034.

Black, F., 1976, “The Dividend Puzzle,” Journal of Portfolio Management 2, 5-8.

Bodnar, G.M. and J. Weintrop, 1997, "The Valuation of the Foreign Income of US Multinational Firms: A Growth Opportunities Perspective," Journal of Accounting and Economics 24, 69-97.

Choe, H., 1990, "Intertemporal and Cross-Sectional Variation of Corporate Dividend Policy," Dissertation manuscript, University of Chicago.

Desai, M.A. and J.R. Hines, Jr., 2004, "Old Rules and New Realities: Corporate Tax Policy in a Global Setting," National Tax Journal 57, 967-960.

Desai, M.A., C.F. Foley, and J.R. Hines Jr., 2001, “Repatriation Taxes and Dividend Distortions,” National Tax Journal 54, 829-851.

, 2002, "Dividend Policy inside the Firm," NBER Working Paper 8698.

,2003, "Chains of Ownership, Regional Tax Competition and Foreign Direct Investment,"

in H. Herrman and R. Lipsey, Eds., Foreign Direct Investment in the Real and Financial Sector of Industrial Countries, Berlin, Springer-Verlag, 61-98. 
$\rightarrow$ Desai, M.A., C.F. Foley, and J.R. Hines Jr., 2006, "Capital Controls, Liberalizations, and Foreign Direct Investment," Review of Financial Studies 19, 1433-1464.

$\rightarrow$ Dewenter, K.L. and V.A. Warther, 1998, "Dividends, Asymmetric Information, and Agency Conflicts: Evidence from a Comparison of the Dividend Policies of Japanese and US Firms," Journal of Finance 53, 879-904.

Fama, E.F. and H. Babiak, 1968, "Dividend Policy: An Empirical Analysis," Journal of the American Statistical Association 63, 1132-1161.

Fama, E.F. and K.R. French, 2002, "Testing Tradeoff and Pecking Order Predictions about Dividends and Debt," Review of Financial Studies 15, 1-37.

Grullon, G. and R. Michaely, 2002, "Dividends, Share Repurchases, and The Substitution Hypothesis," Journal of Finance 57, 1649-1684.

Hartman, D.G., 1985, “Tax Policy and Foreign Direct Investment,” Journal of Public Economics 26, 107121.

Hines J.R. Jr., 1996, "Dividends and Profits: Some Unsubtle Foreign Influences," Journal of Finance 51, 661-689.

Hines J.R. Jr. and R.G. Hubbard, 1990, "Coming Home to America: Dividend Repatriations by US Multinationals," in A. Razin and J. Slemrod, Eds., Taxation in the Global Economy, Chicago, IL, University of Chicago Press, 161-200.

Lang, L., E. Ofek and R.M. Stulz, 1996, "Leverage, Investment and Firm Growth," Journal of Financial Economics 40, 3-29.

Lintner, J., 1956, "Distribution of Incomes of Corporations Among Dividends, Retained Earnings, and Taxes," American Economic Review 61, 97-113.

Mataloni, R., 1995, "A Guide to BEA Statistics on US Multinational Companies," Survey of Current Business 75, 38-53. 